\title{
Bibliographic Instruction: Planning for the Electronic Information Environment
}

\section{Harold B. Shill}

\begin{abstract}
Movement toward an increasingly distributed, electronic information environment places new demands on library instruction programs. Thus, bibliographic instruction should figure prominently in the strategic planning efforts of academic libraries so that it will continue to provide knowledge and skills for lifelong learning in a changing setting. In addition to anticipating new technologies, instructional planning should reflect projected changes in the following: student population, curricula, academic-industrial relationships, scholarly communication, information industry, governmental information activities, schools, public and special libraries, home, work, and income. Ongoing environmental scanning will permit the modification of instructional goals, as necessary, to meet the challenges ahead.
\end{abstract}

cademic research has been enriched in recent years by the use of insights, findings, and models crossing traditional disciplinary boundaries. Similarly, new perspectives on the electronic information environment can be acquired outside the literature of librarianship. Several examples from higher-education literature, airline in-flight magazines, and professional conferences will serve to underscore the differences between librarian and nonlibrarian perceptions of the fast-changing information environment.

In a recent Change article, "Educating for the Information Society," a prominent academic dean observed,

People who do not educate themselves-and keep educating themselves-to participate in the new knowledge environment will be the peasants of the information society. ${ }^{1}$

Nowhere in Harlan Cleveland's thoughtful discussion of problem solving with computer and telecommunications technologies, however, is the word library mentioned. The only reference to libraries is a photograph of a crouching student searching the bottom drawer of a card catalog. This scene offers a vivid contrast to others of enthusiastic, stimulated students using computers.

Cleveland's article, like many others on the social impact of new technologies, is not so much "antilibrary" as "alibrary." The crucial skill for lifelong learning in a fast-changing information environment, he suggests, is "integrative thinking," which he defines as "the capacity to syn-

Harold B. Shill is Evansdale Librarian and Associate Professor of Library Science, West Virginia University, Morgantown.

This paper was originally presented May 15, 1986, at the annual spring conference of the Pittsburgh Regional Library Center (PRLC), held at Chatham College, Pittsburgh, Pennsylvania.

The author gratefully acknowledges the thoughtful comments of Mary Ellen Larson, Pamela Snelson, and Dorothea Thompson on earlier drafts of this paper and the meticulous care taken in manuscript preparation by Karen Retzer and Donna Paes. 
thesize, for the solution of real-world problems, the analytical methods and insights of conventional academic disciplines." ${ }^{\prime 2}$ Computers, in his view, permit cross-disciplinary analyses of complex phenomena that were impossible with print media. ${ }^{3}$ Though few librarians would quarrel with Cleveland's emphasis on "integrative thinking," his neglect of information-retrieval methodology is a major omission.

Airline magazine articles reach a busy, affluent, mobile audience of corporate, governmental, and educational decision makers, leaders who have little time for in-depth reading on any topic. Though seldom cited in scholarly publications, such articles are excellent examples of informative "trend pieces" that bypass the organizational and professional communication channels normally used by these individuals. Given the breadth and power of the audience they reach, such articles have a great potential for shaping elite perceptions and opinions, including views of the emerging electronic information environment.

"'Why make that trip to the little corner library,' wondered Shea, 'when you can tap into an infinitely vaster store of information from your home?' "'

A good example of this genre is a 1984 article, "The Information Explosion," by free-lance writer George Shea. "Why make that trip to the little corner library," wondered Shea, "when you can tap into an infinitely vaster store of information from your home? ${ }^{\prime \prime 4}$ As evidence, he examined in depth the potential uses of home computers for accessing large data banks. ${ }^{5}$ Shea identified CompuServe, Source, and Dow-Jones Information Retrieval Service as the "big three" online purveyors, then noted that Dialog, Mead Data Central, SDC/Orbit, BRS, and the BRS/After Dark service were "worth looking into" for "encyclopedic" access to bibliographic data. ${ }^{6} \mathrm{He}$ also encouraged consumer access from personal computers to Information on Demand customized research, videotex, and electronic mail, bulletin boards, and shopping services and suggested using computer conferences rather than professional journals for access to the latest research developments.

In a similar in-flight magazine article, William Kutik favorably contrasted online searching with manual searching of printed bibliographic tools:

many people have had occasion in high school or college to use the Reader's Guide to Periodical Literature or the New York Times Index for magazine or newspaper research about a subject too current to be in an encyclopedia. That experience usually included tedious searching ... followed by the frustration of making a list of the references, locating the appropriate magazines or microfilm reels . . . laboriously finding the articles, and finally taking notes. ... The whole process-including getting the full text of the articles-can now be performed automatically with on-line databases, which can hold the equivalent of a traditional, large library.

Though he exaggerates the holdings of online files, particularly full-text databases, Kutik advises potential end-users that electronic searching can be costly:

On any service, you're liable to run up a big bill very quickly. It's important to read all the service handbooks, plan your search before signing on, then swiftly get on and off. ${ }^{8}$

Otherwise, like Cleveland and Shea, he fails to address either the intricacies of Boolean searching or the social implications of electronic information systems. Predictably, no mention is made of intermediary searching or search-strategy consultation with librarians or other, disinterested third parties. Yet many influential citizens are forming their initial impressions of the electronic information environment from precisely such articles.

Access to information in a more complex environment is a frequent topic at professional conferences as well. Daily showings of the film Goodbye, Gutenberg, based on Anthony Smith's influential book about videotex, ${ }^{9}$ were featured at the 1983 American Association for Higher Education (AAHE) annual conference, a meet- 
ing structured around the theme "Computers and Telecommunications." Only one session on library roles in the electronic environment was on the conference program.

Finally, at the 1985 Research Libraries Group (RLG) conference, the director of Stanford's data resources group noted that "users are connected to many different sources, of which the library is only one. ${ }^{10}$ Observing that "computers are rivaling books as information-storage and dissemination devices," he further warned, "Libraries might disappear through disuse-through a shift of scholarly research away from libraries toward other places and other media." 11

Though drawn from widely differing sources, these observations on computerbased information systems contain important implications for the academic library's instructional mission. First, the information environment is changing rapidly and independently from the adaptive efforts of libraries. It is increasingly clear that in an era of electronic media and distributed access, the library will not be the primary information resource for many technologically literate individuals.

Second, as a result, libraries of all types face crucial decisions about their role in the new environment. Whether libraries anticipate change and adapt to it or emphasize traditional services through traditional formats, the electronic environment will have a profound impact upon their function as information sources within academic institutions.

Third, the instructional mission of the academic library must be reassessed as we advance into the electronic environment. Librarians must decide whether they will provide bibliographic instruction as traditionally defined or a broader set of skills and knowledge relevant for lifelong selfeducation in an increasingly electronic environment. The selection of the latter approach will require that they present a compelling case for the expansion of human, material, and financial resources to academic administrators in the near future.

This article has a twofold purpose. First, it is intended to convey the importance of strategic thinking and planning for developing bibliographic instruction programs that will provide information-retrieval skills relevant to future work and personal needs. Second, it is designed to demonstrate to administrators the importance of including patron instruction programs in libraries' long-range planning activities.

To pursue these aims, the article examines current library responses to technological innovations, scans environmental factors influencing the instructional mission, and discusses ways of increasing the relevance of instructional efforts for future information environments. Emphasis is placed on the total information environment, rather than on current applications such as online catalogs and database searching. Findings from the environmental scan are presented in order to suggest general directions for an expanded instructional effort, issues to be addressed by instruction librarians, and a planning perspective for electronic information instruction.

\section{"Using learning theories and addi- tional knowledge from education, psychology, and other disciplines, instruction librarians have devel- oped sophisticated user-education programs."}

\section{BIBLIOGRAPHIC INSTRUCTION AND ELECTRONIC TECHNOLOGIES}

Bibliographic instruction has emerged to enjoy widespread, though not universal, acceptance in academic libraries in the last twenty years. Using learning theories and additional knowledge from education, psychology, and other disciplines, instruction librarians have developed sophisticated user-education programs. Advancing beyond an earlier emphasis on library orientation and individual research tools, these new approaches focus on concepts such as information structure and research strategy and use innovative learning approaches such as guided de- 
sign. ${ }^{12}$ Course-related and courseintegrated instruction has displaced the library tour as the preferred form of presentation. Most instructional programs, however, still focus on the use of research tools in the library, whether in print or in machine-readable format.

Efforts to incorporate electronic media into instructional programs have focused on three areas: online catalogs, online databases, and computer-assisted instruction. Academic libraries have also become, in some cases, repositories for microcomputers supporting educational activities not conventionally viewed as part of the library's mission. ${ }^{13}$ A significant literature has emerged in the last six years to document these applications.

Instruction librarians have sought to make use of online public access catalogs (OPACs) as easy as possible through formal instruction, reference encounters, and use aids. Northwestern University has been particularly innovative in planning for patron use of the online catalog, articulating specific learning objectives and systematically monitoring patron searching behavior. ${ }^{14}$ Most OPAC users will need specialized training to take advantage of all the capabilities of an online catalog and to succeed in their searches. ${ }^{15}$

Online database searching has been integrated into many bibliographic instruction programs through lecture/demonstrations and direct end-user training. While intermediary searching is still the predominant delivery mode for this form of online activity, many academic libraries now provide public access microcomputers with user-friendly software ${ }^{16} \mathrm{Oth}$ ers train faculty members and graduate students to perform searches from their homes or offices and may advise patrons on software selection. ${ }^{17}$ Whether performed by end-users or intermediaries, online searches have become an increasingly accepted part of the research process. What has not been extensively recognized, however, is the great contrast between interactive, online searching and the conventional research process. Rather than merely compiling a bibliography, end-users are able to explore new leads and generate new ideas from citation printouts. ${ }^{18}$ This capability is highly conducive to the "integrative thinking" advocated by Cleveland.

Computer-assisted instruction (CAI) has been used in libraries to train both patrons ${ }^{19}$ and employees, ${ }^{20}$ to cover both particular subject resources and general library orientation. Good CAI can provide consistent, high-quality, interactive instruction at any time of the day, night, or weekend. At the University of Delaware, for example, all freshmen complete PLATO instruction modules on the card catalog, periodical indexes, newspapers, and the university library system. This allows librarians to focus their efforts on assisting advanced undergraduate and graduate students in specific disciplines and on developing enhanced CAI modules. $^{21}$

A fourth, more controversial response to campus computerization has been the provision of library space and personnel for computer-related instructional activities. At Texas A\&M a large microcomputer lab, staffed by library personnel, has been built within the library. ${ }^{22}$ At the University of Wisconsin-Parkside, librarians teach students spreadsheet, word processing, and file management applications. ${ }^{23}$ At West Virginia University, librarians have been active in university planning for computer-based education. ${ }^{24}$ This approach has been defended as a way for the library to demonstrate its continued relevance in the electronic environment. ${ }^{25}$ Some, however, criticize in-library microcomputer labs as an unwise diversion from the library's primary responsibilities. ${ }^{26}$

Academic libraries have made significant investments in these four areas, yet there are other electronic technologies for which delivery and instructional commitments have been narrowly focused, minimal, or nonexistent. These include access to consumer utilities, nonbibliographic databases marketed directly to professional end-users, statistical databases, electronic publishing, optical disks, and electronic document delivery. Although a few libraries provide access to the major consumer utilities such as The Source, CompuServe, and the Dow-Jones Infor- 
mation Service, ${ }^{27}$ these utilities, for the most part, focus their promotional efforts on end-users in the home or office. They have subscriber lists that exceed 500,000, yet formal and systematic instruction in the use of their services by librarians is virtually nonexistent.

Specialized database providers also target the end-user. AGNET, for example, provides daily weather, commodity prices, livestock production, and other current information to farmers throughout the country. The EdNET system, through home computers, offers more than forty home-study courses, including testing and direct interaction with instructors. The National Materials Property Data Network (NMPDN) has begun to provide engineers with direct access to numeric data on "the mechanical and other properties of materials. ${ }^{28}$ In all these cases the focus of the marketing effort is the end-user rather than potential intermediaries.

Access to numeric databases on campus has usually been provided by a nonlibrary unit such as the University of North Carolina's Institute for Survey Research. These organizations maintain magnetic tapes, codebooks and manuals; search and manipulate data files; and instruct end-users in searching and processing aggregate data. Although there is growing awareness among librarians of the need to access numeric data files, ${ }^{29}$ such as those maintained by the Inter-University Consortium for Political and Social Research (IUCPSR), the National Opinion Research Center (NORC), and pollster Lou Harris, ${ }^{29}$ actual searches of statistical/numeric files have been conducted primarily in databases provided by such familiar online services as Dialog and BRS. A recent survey of fifty-five ARL libraries found that in-library searching of numeric databases was done almost exclusively by librarians, not by users. ${ }^{30}$ In addition numeric files receive little mention in online service publicity. ${ }^{31}$

In the library literature, electronic publishing has largely been viewed as posing problems, e.g., of cataloging and access, rather than opportunities. ${ }^{32}$ The implications of electronic publishing for techno- logically sophisticated end-users have received minimal attention, except in the writing of futurists. ${ }^{33}$ Instruction librarians appear to be making little effort to provide basic end-user orientation and training in searching full-text databases and electronic bulletin boards and knowledge databases such as New Jersey Institute of Technology's Electronic Information Exchange System (EIES).

\section{"The professional end-user is clearly the chief marketing target of compan- ies developing CD-ROM and CD-I products."}

Nor does the literature contain adequate discussion of patron training for searching databases stored on optical disks. This vacuum should be filled: the professional end-user is clearly the ultimate marketing target of companies developing CD-ROM and CD-I products. ${ }^{34}$ Proponents of optical disk technology argue that the predictability of its cost, because there are no telephone and database connection charges, should stimulate searching activity. The National Agricultural Library's current experimental distribution of the Agricola database, on laser disk, to land-grant libraries may provide evidence of $\mathrm{CD}$ ROM's long-term viability. ${ }^{35}$ Whether participating libraries opt for intermediary or end-user access to optical disk databases, this technology clearly has potential for widespread use in a variety of settings.

Finally, electronic document ordering and delivery systems such as UMI's Article Clearinghouse and Artifax services and ISI's Genuine Article tear-sheet service have been perceived by librarians primarily as an enhancement of document delivery through the library. It is not, however, predetermined that libraries will remain the sole point of access to these services. Advanced workstations such as the UMI prototype and Rosenberg's selfcontained scholar's workstation will have the capacity to download data, text, and citations from remote online databases, access local area networks (LANs), search 
databases stored on optical disk, and receive telefacsimile transmissions from distant sites. ${ }^{36}$ Commercial vendors will aggressively pursue the end-user market once such workstations are fairly common. Some document delivery services, including Information on Demand and the Report Store, already focus their marketing efforts on the information consumer rather than on the library. Indexing services and professional societies such as the Public Affairs Information Service (PAIS) and the American Mathematical Association have also entered the document delivery business. Instruction librarians, however, generally emphasize the library's ability to secure in a few weeks documents that are not available locally.

\section{PLANNING FOR THE NEW TECHNOLOGIES}

Notwithstanding their positive responses in some areas, e.g., online catalog design and CAI, academic librarians' instructional stance toward new technologies has, on the whole, been reactive rather than anticipatory. Instructional implications are generally addressed after a new technology has been selected, rather than before. Seldom are efforts made to integrate new technologies into a larger conception of instructional plans and priorities. This reactive posture is reflective of a tendency to plan according to the annual-report cycle and to project past experiences into the future, rather than looking beyond to long-term, strategic planning for bibliographic instruction and other services. The argument often heard is that change is so rapid and unpredictable that planning more than two to three years ahead is futile.

Undoubtedly, predictions become increasingly fuzzy as we project further into the future. A refusal to plan for the long haul, however, both dooms libraries to a permanently reactive posture and enhances vendors' ability to manipulate the information environment. Providers of information technologies perform extensive market research before investing heavily in a new product and work actively to create a market for their products. Accordingly, major database vendors now dem- onstrate their products to potential customers at major disciplinary (Modern Language Association, American Psychological Association) and professional (American Medical Association, American Association for the Advancement of Science) conferences. Marketing staff present both intermediary and end-user searching options to these audiences. Prospective customers, however, could still come away with an overoptimistic impression of their immediate searching potential and would benefit from library guidance regarding system capabilities and shortcomings. Popular articles, including those in airline magazines, promote such a sanguine perspective. Instruction librarians have a responsibility to educate members of the academic community in both the opportunities and pitfalls of new information technologies.

There are many models for strategic planning, but library literature on the subject is sparse. ${ }^{37}$ Little long-term, acrossthe-board consideration of instructional choices can be found in the library planning, automation, or bibliographic instruction literatures. The focus of most future-oriented articles is on teaching the use of individual access systems, such as online catalogs or personal computers, rather than on systematic treatment of evolving information-access needs in an increasingly electronic, distributed-use environment. Two notable exceptions are the Tennessee and Texas A\&M studies of information needs and user services in the electronic environment. ${ }^{38}$

Strategic planning models vary in content, but all normally include a definition of organizational mission, a statement of goals, and a list of objectives. A planning exercise will help to move the organization from its current situation to a "desired future" by identifying opportunities, competition, environmental trends, and clientele needs and then devising strategies for reaching objectives and moving toward long-range goals.

Environmental scanning, which should be a key component of every strategic plan, can be described as the monitoring of the environment outside the immediate organization for new developments that 
"External, nontechnological developments must be addressed if instruction for future information needs is to be adequate."

present threats or opportunities. A taxonomy is usually employed to structure the scanning process. At the University of Minnesota, for example, institutional scanning efforts are divided into political, economic, social/life-style, technological, and demographic/manpower areas. ${ }^{39} \mathrm{Par}-$ ticipants in each area meet regularly to review and modify the plan in response to internal and external developments. In the academic environment the scanning function is usually performed by an office of institutional research. The most prominent strategic planning examples in the library community are the efforts of ALA, ACRL, and the Public Library Association.

\section{SOCIAL CHANGE, NEW TECHNOLOGIES, AND THE INFORMATION ENVIRONMENT}

It is widely recognized that evolving information technologies will have a profound effect upon academic libraries in the next ten to fifteen years. However, less attention has been given to other social, economic, institutional, and political forces in forecasting the future of academic libraries in the electronic information environment. It is a central argument of this article that external, nontechnological developments must be addressed if instruction for future information needs is to be adequate. In order to illustrate the potential impact of external variables, a rudimentary environmental scan has been performed. The implications of this scan are considered at the end of this section, and appropriate instructional responses to the scan are suggested in the conclusion.

For present purposes, an academic library is conducting the scan. Ten environmental factors pertinent to the library's instructional mission will be examined in this section-population, home, schools, work and income, governmental support, information industry, public libraries, higher education, scholarly communication, and new information technologies. The scan illustrates the range of external factors that may affect library instruction. It is not exhaustive, so such lowprobability, high-impact factors as thermonuclear war, desertification, depletion of Earth's ozone layer, and rapid melting of the polar ice cap have been omitted. The selected factors have a real, if not an obvious, impact upon the information environment. Technology is treated as one among many environmental influences in order to emphasize the importance of the other social forces, often neglected in the library literature, in determining the shape of the coming information environment.

\section{Factor 1: Population}

In Academic Strategy, George Keller projected a 25 percent decline in the traditional college-age population between 1979 and $1994 .^{40}$ The magnitude of this decline will vary from state to state, but it will be greatest in the Northeast and Midwest. Rhode Island will experience the largest drop, projected to be 49 percent. ${ }^{41}$ Growth in this age group, as in the general population, will be greatest in the Sun Belt states ranging from Virginia to California.

More recently, John Budd and David Robinson used National Center for Educational Statistics data to predict that higher education enrollment would decline 5.4 percent between 1984 and 1993. They anticipated the greatest change at the undergraduate level, where a 7 percent decline would follow an increase of 42 percent in the 1970s. Slight increases were projected in the over-twenty-five, part-time, first graduate degree, and professional categories. ${ }^{42}$

The United States is also experiencing a significant change in the ethnic and racial composition of its population, with new immigrants coming primarily from Third World countries, while existing Hispanic, black, and Asian groups are growing faster than the Caucasian population. With 4.3 million legal immigrants and 7 
million illegal aliens entering the country in the 1970 s, colleges will be accommodating a more heterogeneous group of students with diverse cultural, linguistic, and social backgrounds. ${ }^{43}$

The implications of these demographic trends have not been lost on academic administrators, who have escalated their recruitment campaigns. These efforts have been successful, and total enrollment has stabilized at approximately twelve million students. ${ }^{44}$ Though some institutions have lowered admission standards, enrollment stabilization has been achieved primarily through student recruitment outside the traditional college-age population and concentrated efforts at student retention. Assumptions about age-group homogeneity will become less valid as a more culturally diverse student body enters college.

\section{Factor 2: Home Environment}

Domestic life has changed profoundly in the past twenty-five years. Most notable is the sharp increase in single-parent families and in families in which both parents work outside the home. Day-care centers have brought structure to the lives of many children, but the long-term effect of contemporary child-rearing practices upon the social and educational development of children is still an unresolved question in educational research. ${ }^{45} \mathrm{It}$ is anticipated that an increasing percentage of freshmen will be former latchkey children and children from single-parent homes.

The invasion of the home by visual entertainment media is likewise a major development in childhood socialization. Researchers have consistently found that children today read less and watch television more than did their counterparts twenty years ago, and a specialized journal (Television and Families) has been devoted to this subject. The rapid penetration of home and school environments by the videocassette recorder (VCR) in recent years will reinforce this preference for passive, visual entertainment.

A third revolution in the home environment is the presence of the microcomputer. As of January 1986, 19 percent of all
American homes had a microcomputer, and an increasing number had acquired a modem. ${ }^{46}$ However, computing resources are distributed inequitably. Although television commercials have exaggerated the impact, there will probably be a widening technological literacy gap between students who have home computers and those who do not. The potential for a significant gender gap also exists, because 93 percent of current home-computer users are male. ${ }^{47}$

\section{Factor 3: Schools and Learning}

During the past twenty years, elementary and secondary schools have experienced steady decline in the quality of instruction due to low teacher pay and prestige, retirement or resignation of many excellent teachers, higher-paying careers opening for women and increased discipline problems. One result of deteriorating school performance has been an increase, to twenty-seven million, in the number of illiterate adults in the United States. This is a social problem with grave long-term implications in a country where basic literacy, not to mention technological competence, will be a sine qua non for effective participation in the information society.

"Growing societal dissatisfaction with the schools' direction crystallized in 1983 with the publication of A Nation at Risk."

Growing societal dissatisfaction with the schools' direction crystallized in 1983 with the publication of $A$ Nation at Risk, the report of the National Commission on Excellence in Education. Five "new basics" were emphasized in this blue-ribbon panel's report including instruction in computer science enabling high school graduates to

(a) understand the computer as an information, computation and communication device; (b) use the computer in the study of the other basics and for personal and work-related pur- 
poses; and (c) understand the world of computers, electronics and related technologies. ${ }^{48}$

In fact, the schools had already anticipated the need for computer competencies, and the number of schools with at least one microcomputer had increased from 18.2 percent in 1981 to 92.2 percent in 1985. ${ }^{49}$ Thus, academic institutions will experience a corresponding rise in the computer competencies of entering freshmen in the next few years.

Frequently, school libraries are becoming repositories for microcomputer laboratories, and many have acquired online catalog and/or circulation systems. Many school libraries have also introduced online database searching. This activity has increased geometrically since librarian intermediary searching was introduced in Montgomery County, Maryland, in 1976. ${ }^{50}$ The first reported end-user training for high school students occurred at Radnor High School (Pennsylvania) in $1980 .^{51}$ As of April 1987, nearly 1,600 educational institutions, approximately half of them high schools, had enrolled in Dialog's classroom instruction program. That total represents an increase of 700 participants since January $1986 .^{52}$ BRS and Wilsonline also have active classroom programs for instructional access in schools. ${ }^{53}$ Students graduating from schools with online catalogs and database services will have higher expectations for information technologies than many of their classmates.

\section{Factor 4: Work and Income}

In the best-selling book Megatrends, John Naisbitt observes that we are moving from an industrial society to a knowledgebased, information society. ${ }^{54}$ For workers in many basic industries, this shift has meant that high-paying jobs lost to automation and foreign competition have been replaced by lower-paying service jobs, including some in cottage industries. The physical barriers between work and home have also become blurred with the rise of telecommuting.

On the other hand, and paradoxically, a trend toward a shorter work week offers more time for leisure activities. While the average employee may have more time to engage in personal information seeking, he or she will have fewer resources to pay for fee-based services. These services, in turn, are expected to proliferate and in many cases will replace print products.

\section{Factor 5: Information and Government}

The future role of government in information dissemination remains uncertain. It is clear, however, that the Reagan administration has created a political agenda that emphasizes shrinking the federal government and shifting many governmental activities to the states or the private sector. The American Library Association has repeatedly opposed administration initiatives to eliminate funding for major library programs; reduce government publication activities (OMB Circular A130); "privatize" government information; create a "sensitive but unclassified" category for some federal documents; end revenue sharing and the deductibility of state and local taxes (a prime financial support for local education); limit data collection and access; contract out federal libraries to private firms; and discourage development of a national information policy. Although the long-term impact of the Reagan "revolution" upon the information environment remains to be seen, it is likely that the federal government will be less active in this area as efforts to meet Gramm-Rudman-Hollings' deficit reduction targets continue and the administration's antigovernment bias lingers.

The impact of reduction in federal support for education and libraries will vary by state. In low-income, low-tax base states such as West Virginia, where federal revenue sharing dollars have accounted for 22 percent of local contributions to public library funding, the effect will be profound. One West Virginia county has lost public library service altogether, while others have closed temporarily, as limited funds are dedicated to police and fire protection and other "basic" services. ${ }^{55}$ Unless alternative sources of funding are developed, students from poorer states will become increasingly disadvantaged in exposure to both traditional library resources and new information technologies. Other states, such as Minnesota, have saturated their schools 
with computers, while Tennessee has pioneered in the use of teacher merit pay to upgrade the quality of elementary and secondary education.

The support of education and libraries by local government will vary according to local tax bases, community income, voter support for bond issues, and local elite preferences. Although many school libraries have benefited from Education Consolidation and Improvement Act (ECIA) Chapter 2 funds, direction of these federal monies to library/media centers has been very uneven since block grants replaced thirty-one categorical grant programs in 1982. ECIA will need to be reauthorized by Congress in 1987, and the amount of funds reaching school libraries will depend on the disbursement provisions set by Congress. ${ }^{56}$ Intrastate differences in preparing students for the information society will continue to grow as students from affluent, educationoriented districts receive the best precollege training in information retrieval skills.

\section{Factor 6: Information Industry Structure}

The most significant trend in the information industry, in addition to the development of consumer-oriented information services, such as The Source and CompuServe, has been its inexorable movement toward economic concentration. For example, Canada's International Thomson Organization has acquired Carrollton Press (producer of the REMARC database), Gale Research Company, and Utlas, giving it a firm foothold in the production of machine-readable bibliographic records, reference materials, and online library systems. Aggressive private publishers, such as Elsevier and Pergamon, are taking over society publications, university presses, and database vendors such as SDC while actively denouncing federal information programs as "unfair competition." Conventional publishing houses such as McGraw-Hill and Macmillan have developed electronic publishing divisions that produce computer software in addition to books and journals. Bell and Howell, a major producer of microform readers, has taken over University Microfilms, a major producer of microform products, which in turn, has acquired Data Courier, an important vendor of business and pharmaceutical databases. Reed Publishing, which has advocated privatization of the National Technical Information Service, has purchased Cahners, the new publisher of Library Journal.

These trends toward both horizontal and vertical integration of the information industry are harbingers of reduced competition, higher prices, increasing reliance on fee-based services, and the domination of the information sector by organizations whose primary concern is profit, rather than dissemination of knowledge.

\section{"The overarching technological question in the information industry is the long-term result of the shake- out between print and online pub- lishing."}

\section{Factor 7: Technology and Access}

The overarching technological question in the information industry is the longterm result of the shakeout between print and online publishing. Reporting on a Delphi study, F. Wilfrid Lancaster predicted in 1982 that 25 percent of all reference books would be available only in electronic form by 1990 , that 50 percent of all technical reports would be accessible only in machine-readable form by 1995 , that 25 percent of all journals would be published exclusively in electronic form by 2000 , and that fully 50 percent of all abstracting/indexing services would be unavailable in print by $2000 .^{57} \mathrm{He}$ also predicted that the "migration from print" would occur first in the literatures of science and technology, followed by the social sciences, the humanities, and finally, popular literature. ${ }^{58}$ In 1985 he contended that many of his earlier projections about the "paperless" society were already being confirmed by technological developments. ${ }^{59}$ 
Other developments that will affect access to information are library automation, telecommunications advances, improvements in computer hardware, links between computer systems, "intelligent" searching software, direct document delivery, optical disk technology, desktop publishing, and electronic document databases. Given the extensive coverage of new technologies in the library, computer, and higher education literatures, and the overview purposes of this environmental scan, in-depth consideration of individual technologies is not needed here.

\section{Factor 8: Public Libraries}

The public library has long provided access to both materials and information for most adults who have completed formal education. It can be anticipated that wellfunded, innovative public libraries will thrive as they meet new demands and adapt to the electronic environment. The Pike's Peak Library, which serves as an online information center for the Colorado Springs community, may be regarded as the prototype of the future. ${ }^{60}$

Less-affluent public libraries, on the other hand, may be forced to reduce hours, acquisitions, and services while confronting a new set of demands generated by the electronic environment. ${ }^{\text {. }}$ Such libraries will become increasingly marginal for their technologically literate patrons, and private vendors may step in to fulfill unmet needs. As their visibility recedes, private-sector competitors emerge, federal support diminishes, and publishers challenge government's information activities, many of these public libraries may disappear.

\section{Factor 9: Higher Education}

Academic libraries must be sensitive to changes in the institutional environment and in the teaching, research, and service missions of their parent institutions. Demographic and curricular change, university-industry partnerships, the "wiring" of the campus for local area networks (LANs) and remote computer access, and possible library/computer center mergers are the most significant areas for library administrators and instruction librarians to monitor.

Keller reported that 40 percent of all college students in 1980 were enrolled parttime, while 36 percent of the student body was over the age of $25 .^{62}$ Extension and evening/weekend instruction, whether delivered on campus, by traveling faculty members, through computer-assisted instruction, or via satellite and microwave links, is likely to become increasingly important for reaching nontraditional students.

The number of international students in American institutions has increased dramatically, from 145,000 in 1970 to 321,000 in 1982. Their impact has been especially noticeable in applied disciplines such as agriculture and engineering. In 1980 foreign students accounted for 33 percent of the enrollment in these disciplines. ${ }^{63}$ Since 1981 more than 50 percent of all U.S. doctorates in these fields were awarded to foreign students. ${ }^{64}$ It should also be noted that the number of students from China is likely to rise. Thus, nontraditional students, whether older or of foreign origins, will comprise an increasingly large proportion of enrollment as we move toward the 1990 s.

Curricular change in recent years has reflected societal perceptions of opportunity and educational need. Disciplines that provide knowledge directly relevant to postcollege employment, such as business administration, computer science, and engineering, have experienced significant growth. A shift toward cultural conservatism by students has also stimulated enrollment growth in most applied disciplines.

Federal sponsorship has long been a vital stimulus to university research. ${ }^{65} \mathrm{Col}-$ leges have also benefited from federal support, which expanded into other disciplines and academic environments after the war. The current recession of federal involvement in higher education, however, has underscored the importance of academic relationships with private industry and business funding sources. Though Robert Rosenzweig and others have written extensively about emerging university-industry relationships in re- 
cent years, only a few writers address library-business relationships. ${ }^{66}$

Progressive academic institutions have adopted campus computing strategies, including automation priorities and vendor purchasing guidelines. Some such as Carnegie-Mellon, Drexel, and Drew, have also mandated that incoming students acquire a specific make of microcomputer. ${ }^{67}$ In addition to library databases, many files are already maintained by campus computer centers, research institutes, academic departments, and university administrations. The IAIMS (Integrated Academic Information Management System) concept advanced by Nina Matheson and Patricia Battin directly addresses the issue of decentralized databases in a wired campus environment. ${ }^{68}$ Provision of campuswide access to local information systems offers many opportunities for library-computer center collaboration.

The wired campus can provide enhanced access to both local online and external databases and electronic messaging systems. ${ }^{69}$ Computer centers already make connections to outside systems through Telenet, Tymnet, Bitnet, CompuServe, The Source and other services, as do academic departments and individual faculty members.

\section{Factor 10: Scholarly \\ Communication Patterns}

A final environmental factor that influences the instructional mission is the evolution of scholarly communication systems in the electronic environment.

Academic libraries have traditionally provided access to the formal communication systems of academic disciplines through catalogs, abstracting and indexing services, and bibliographies. These print-based services are now complemented by a multitude of online files whose users are developing a whole set of new information-seeking behaviors.

Informal communication systems such as Price's "invisible colleges" have been largely neglected by instruction librarians, though they are well-documented in studies of scholarly communication. ${ }^{70}$ Informal communication systems have flourished in the past through conventional channels such as letters, telephone calls, and faceto-face discussions at professional conferences. Advances in computer and telecommunications technologies will profoundly influence the future structure and importance of invisible colleges. ${ }^{71}$ In fact, preliminary evidence of this transformation is already available.

Scholars can now submit manuscripts to publishers on flexible disks, and there is no reason to assume that telefacsimile, electronic file transfer, and other technologies will not be used similarly in the future. Electronic manuscript delivery is merely a format change at one stage of the publication process, not a radical departure from existing scholarly communication systems. However, computer conferencing, electronic publication databases, and desktop publishing will pose formidable problems for bibliographic control in traditional systems.

\section{"Computer conferencing should greatly streamline the scholarly com- munication process."}

Computer conferencing should greatly streamline the scholarly communication process, as both ideas and manuscript drafts can be reviewed interactively with colleagues at distant sites prior to their submission for publication. The primary drawback of this method will be the continued insulation of these communications from colleagues outside the invisible college who might offer useful suggestions on work in progress or benefit from the ideas themselves.

Electronic databases mounted by individual institutions or consortia will also permit scholars to examine research in progress. $^{72}$ If depositing finished documents permanently in such systems becomes an academically acceptable form of publication, important new databases will be created outside existing bibliographic control systems.

Desktop publications, finally, may prove to be the most elusive documents of 
all, since their existence will not be known until they are incorporated into standard bibliographic sources, such as the OCLC Union Catalog. As new technologies are used more widely, information overload is likely to affect scholars and students, and quality control will be difficult to maintain, given both the capability for searching remote databases and the current completion rate of 7,000 scientific articles per day. ${ }^{73}$

\section{Summary}

While not necessarily exhaustive, these ten factors illustrate the breadth and importance of environmental scanning for future instructional planning efforts. Developments in these areas carry enormous implications for higher education and academic libraries and for society at large. They must be actively addressed in instruction programs if we are to prepare our students and faculty for effective lifelong functioning in the electronic information environment.

Instruction for lifelong learning must convey the fluidity of the information environment; cover key institutional sources of information, e.g., public library, private vendors, and government; and suggest strategies for maximizing retrieval while minimizing cost. Perhaps most importantly, instructional planning must take into account changes in scholarly communication and in the higher-education environment itself. As electronic and informal communication channels gain importance, it will be the librarians' task to promote these systems and teach users how to access and manipulate them.

Higher education will be transformed significantly by four factors: (1) rise in nontraditional and foreign student enrollment; (2) growing use of computer and telecommunications technologies for research, teaching, and service; (3) expansion of vocational curricula to attract an employment-conscious student body; and (4) development of academicindustrial partnerships.

Meeting the instructional needs of nontraditional students will require flexible scheduling to permit instruction during evening and weekend hours. Instruc- tional delivery to off-campus sites requires librarians at Central Michigan University and the West Virginia College of Graduate Studies to travel extensively. Another option is the development of instructional packages for remote delivery via satellite, microwave, or computer-assisted instruction. The needs of foreign students may best be met by early contact, preferably in small groups, during campus orientation programs. Such students will be an increasing target of university recruitment efforts during the next decade, and both imagination and a certain amount of specialization will be required to meet their needs.

With the growing use of new technologies, librarians need to know the uses of these technologies and educate campus administrators and faculty on their potential. The new technologies can deliver instruction to remote sites (on and off campus), search local and distant databases, transfer files electronically, and transmit discrete bits of data or whole documents directly to the library or the end-user. It is important that key decision makers do not perceive the library as a self-contained warehouse when LAN and off-campus delivery decisions are made. Library/computer center mergers give one indication of how libraries may evolve. ${ }^{74}$

The shift in curricular emphasis is particularly important for diverse groups of students, such as freshman English classes, where academic major-related instruction may be more effective than literary or general fact-finding exercises. Establishing the library's relevance to personal information needs is particularly important at this stage of a student's career. If the habit of systematic online searching is not established early, it is likely that the student will rely on informal contacts or be misled by the potential of electronic database searching after graduation.

Finally, two slightly different aspects of industry/higher education relationships have significant implications for academic libraries and their instructional mission. First, because access to private funding depends heavily on the quality of a university's faculty and its research, libraries 
should develop local collections to support industrial-academic research ventures and expand faculty instruction in the identification and use of appropriate access tools.

Second, publicity about library resources should be sent to both corporate and small business representatives. Library resources permitting, this effort could include publicity about fee-based information delivery programs, such as the Michigan Information Transfer Service or Carnegie-Mellon's PLAID. This type of instructional effort will solidify industryuniversity relationships and contribute to local, state, and regional economic development. In addition to strengthening the institution in its quest for private sector support, it will also enhance the library's position within the university or college and may stimulate private financial support for the library.

\section{ELECTRONIC INFORMATION, PATRONS, AND THE \\ ACADEMIC LIBRARY: TOWARD A "DESIRED FUTURE"}

The advent of distributed, electronic access to information presents enormous opportunities and significant risks for the information consumer as well as the library. Among the benefits are greater access for some (the technologically literate and affluent), the ability to exert greater control over one's own searching, ${ }^{75}$ computer-age receptivity to innovative uses of technology, and the chance to expand searching skills over time as computer-based systems are used regularly.

The risks of the electronic environment may be less apparent to patrons, though librarians should be acutely sensitive to them. These risks include (1) erosion of the formal communication system and its supporting bibliographic apparatus, with increasing reliance on informal, electronic communications; (2) emergence of significant gaps in the information structure of various disciplines; and (3) user ignorance of relevant databases, the content of such databases, and the shortcomings of their search strategies. Artificial intelligence and generalized "front ends" may allevi-

\section{"Instruction librarians should also be aware of the long-term social con- sequences of Lancaster's 'migration from print on paper.' "'}

ate some of the technical problems of enduser searching, but instruction librarians have an ongoing responsibility to educate their patrons in the deficiencies, as well as the capabilities, of the new information technologies.

Instruction librarians should also be aware of the long-term social consequences of Lancaster's "migration from print on paper. ${ }^{176}$ While some types of information will certainly remain available in print, others will be produced in electronic form only from the outset and still others will be available in both formats (parallel publishing) during a transitional period. Electronic information services will normally be fee-based. Librarians should obtain search subsidies, instruct patrons in cost minimization, and teach them to use print alternatives.

Patrons should be made aware of the potential for gaps in long-maintained data files and the existence of alternative sources for data that have been collected but not published. Data gaps will become an increasingly significant instructional concern as academic libraries provide access to machine-readable files.

A third potential development is the substitution of computerized file browsing for conventional reading or scanning of books and journals by affluent and technologically sophisticated information users. Concern has been expressed that by relying on electronic database searches, students may miss the enriching educational experience of browsing through bibliographies, footnotes, printed indexes, and library stacks." However, as Joseph Raben has noted, online files provide the opportunity for a broader and more focused form of browsing:

In the existence of online encyclopedias, for example, lies a possibility for encouraging students to follow individual lines of inquiry, not 
only within subjects but across them. Such students, truly browsing and selecting information that links with already required knowledge, may not be only educating themselves in particular subjects, but also learning the most important skill-how to acquire knowledge. ${ }^{78}$

Studies are needed to determine the effectiveness of selective online browsing and SDI services versus conventional scanning or reading, but we can anticipate that new, more powerful types of online browsing will refine and enhance the experience of "learning the literature." The process may change, but the ideagenerating potential of online searching is far greater than that of print indexes without any real sacrifice of the potential for serendipitous discovery.

Studies of actual use of all types of electronic information systems are also needed. Knowledge of how users interact with online systems will enable us to identify areas where instructional refinement is needed and learn alternative search methods from patrons' coping strategies. Findings from such studies should be incorporated into instructional methods for online information consumers. Feedback from use studies should also be given to system designers.

In defining the appropriate library response for the transition to the electronic information era, we must first ask the fundamental question, What is our business? Naisbitt cites the railroad industry, which belatedly recognized that it is in the transportation (not railroad) business, as a prime example of institutional failure to adjust its mission statement as new transportation technologies evolved. ${ }^{79}$ In their book In Search of Excellence, Peters and Waterman advise businesses to "stick to the knitting," to focus on activities they know best rather than diversifying beyond their span of knowledge and competency. ${ }^{80} \mathrm{~A}$ good definition of academic libraries' business would incorporate both sets of advice.

It is tempting, in an era when computer use is increasing rapidly and is at least tacitly linked to organizational relevance in popular understanding, to seize every opportunity to acquire and use microcomputers in support of higher education ac- tivities. Appealing as these opportunities may be for pursuing institutional goals and altering traditional perceptions of the library, they ultimately divert human and material resources from the library's central mission. The mission can be defined quite simply as the provision of intellectual and physical access to information and knowledge. Instructing users to access information, both inside and outside the library and regardless of format, is a goal whose achievement is central to the library's continuing mission. Instruction in microcomputer use, however, is analagous to instruction in writing and reading skills, two tasks libraries have properly avoided despite their obvious relevance to the use of printed materials. With the pervasive excitement over computer and telecommunications technologies, however, we may forget that new technologies are merely instruments for attaining that larger goal and not ends in themselves. If we are to provide relevant instruction for the electronic age, we must retain that distinction and not make long-term commitments to roles peripheral to the library's mission, such as microcomputer instruction.

In addition to focusing clearly on the library's mission, goals and objectives, instruction librarians must also develop regular channels of communication with school, public, and special librarians. The recent Carnegie Commission report, $\mathrm{Col}$ lege: The Undergraduate Experience in America, has emphasized the transition from high school to college as a major "discontinuity" adversely affecting undergraduate education. ${ }^{81}$ The report also directly addresses the library's instructional role:

All undergraduates should be introduced carefully to the full range of resources for learning on a campus. They should be given bibliographic instruction and be encouraged to spend at least as much time in the library-using its wide range of resources-as they spend in class. ${ }^{82}$

Contact with school librarians is essential for knowing the information retrieval background of incoming freshman. As secondary schools rapidly add database searching services, provide extensive exposure to microcomputers, and acquire automated catalog and circulation sys- 
tems, the information retrieval sophistication of incoming freshmen will be changing significantly from one year to the next. Similarly, school librarians should be aware of the information environment awaiting their college-bound students so that appropriate preparatory training can be given. However, we must also be prepared to address the needs of students from "have-not" districts and to maintain a dialogue with their librarians as well.

\section{"Communication with public librar- ians is vital in preparing students for postcollege information retrieval and in understanding the post-high school information background of many returning, nontraditional stu- dents."}

Communication with public librarians is vital in preparing students for postcollege information retrieval and in understanding the post-high school information background of many returning, nontraditional students. Whether they eventually settle into an affluent, progressive community like Colorado Springs or a poorer town with an underfunded public library (or none at all!), our students will need to be aware of the public library as a vital, evolving alternative to fee-based services marketed directly to the end-user. Knowledge of public library services is also essential for comprehending the post-high school information experiences of nontraditional students, whether or not they have actually used public libraries. Nontraditional students are also likely to appreciate the information potential of the public library, having experienced real-life information dilemmas.

Familiarity with trends in special libraries is likewise imperative, since many students going into a corporate, governmental, or legal environment will have access to their unique (and often proprietary) resources. Appreciation of change in the information environment, the services provided by special libraries, and the value and ease of access to information for decision making will be particularly useful for both traditional and nontraditional students anticipating careers in these areas.

The other nontraditional cohort, the international group, presents a more difficult long-term planning problem. In addition to having language and cultural difficulties, foreign students come from national information environments ranging from very advanced to primitive. Because most international students in the United States come from Third World countries that represent an increasingly important institutional market, it is appropriate that instruction librarians acquire at least a general knowledge of library services in the less-developed countries (LDCs). This knowledge may be acquired through courses in comparative librarianship, programs at library conferences, or through individual study. While familiarity with $130+$ national library systems is clearly not a realistic expectation, some knowledge of general patterns in Third World library systems, including present and future access to major database and document delivery services, is imperative if we intend to prepare foreign students as well as their American peers for lifelong learning.

Implicit in this discussion of communication with nonacademic libraries is the assumption that environmental factors must be scanned not as discrete, isolated phenomenon, but as elements of a larger, holistic information environment. Just as it is essential that our response to change include linkages with other types of libraries, it is also vital that we appreciate the complex interrelationships among social, political, and economic changes in the information environment. Too often we assume that technology is the sole driving force behind developments in the information sector. By ignoring other environmental influences, however, we can neither anticipate and understand changes in the information environment nor give our students a truly adequate conceptual preparation.

Viewed from this perspective, an effec- 
tive, evolving instruction program is an essential objective for achieving the strategic goal of user training appropriate for the information age. Such a program should ideally be progressive and cumulative. It should build on prior experience and initial instruction for local information systems eventually to impart: (1) an understanding of formal and informal communication systems; (2) familiarity with the tools and strategies needed to access those systems; and (3) awareness of the inevitability of change and its likely direction as new technologies emerge and social, political, and economic conditions evolve. The learning outcome should be a thorough grounding in information organization/retrieval concepts and print/ online searching skills appropriate for lifelong learning in varied work and living environments during an era of constant, rapid change.

If such a program is to be developed, it is essential that instructional objectives be incorporated explicity into the long-range planning process of the library. Specific information competencies, such as the Colorado Library Association's "information literacy" goals, should be adopted as program targets. ${ }^{83}$ Administrative support, both human and material, must be increased if instructional aims are to be achieved. Program performance should be reviewed regularly through posttesting and long-term feedback. Learning objectives should be modified as information technologies and institutional curricula change. The adoption of an activity name more reflective of the new environment, such as "information instruction," could direct academic librarians toward a new set of objectives.

The form and scope of the library's planning for information instruction will significantly affect its future role on the wired campus as well. At best, it can become a thriving communication node, responding to changing information needs and anticipating new social and technological developments. The Pike's Peak Library and the IAIMS concept can be regarded as trailblazing efforts in that direction. At worst, the library may become a print re- pository, abdicating responsibility for providing and teaching access to machinereadable files and other online, "non-library" information to departmental data libraries, consumer utilities, and campus computer centers. These organizations are the library's natural competitors in the electronic environment, our frequent and desirable collaboration notwithstanding. If a passive stance is adopted, the traditional library will sink slowly into the post-Gutenberg obscurity predicted by Lancaster. ${ }^{84}$

By adopting "information literacy" as one of its strategic goals, the library will encourage a significant redefinition of its role on campus. First, it will enhance campus perceptions of the library as a permanent, indispensable resource whose mission is to provide access to information and knowledge in any format. Second, by focusing upon lifelong information competencies as an instructional goal, the library will demonstrate a clear capacity for useful adaptation to environmental change. Third and most important, the library will gain visibility on campus by proving its effectiveness in providing access to information and may, as a result, command a larger share of institutional resources.

If librarians do not apply their bibliographic and instructional skills to training for electronic era information retrieval, their institutions and patrons will suffer. As Bob Dylan observed in a somewhat different context, "He who gets hurt will be he who has stalled." ${ }^{185}$ The first step toward effective instruction for the electronic environment is to recognize information literacy as a central goal in the long-range planning process. A clear statement of instruction objectives for a "desired future," one far broader than development of course-related and courseintegrated instruction, must also be formulated. Our students are preparing for a future in which change will be constant and often unsettling. It is our responsibility, as academic librarians, to provide them with the conceptual framework and skill base they will need to exploit the information environment and thus avoid becoming its "peasants." 


\section{REFERENCES AND NOTES}

1. Harlan Cleveland, "Educating for the Information Society," Change 17:21 (July/Aug. 1985).

2. Ibid., p. 21.

3. Ibid., p.20.

4. George Shea, "The Information Explosion," USAir, 6:42-44, 51-54, 71-79 (July 1984).

5. Ibid., p.51, 72 .

6. Ibid., p.51.

7. William M. Kutik, "The Knowledge Network," Eastern Review: The Magazine of Eastern Airlines, May 1986, p. 97.

8. Ibid., p. 99 .

9. Anthony Smith, Goodbye Gutenberg: The Newspaper Revolution of the 1980s (New York: Oxford Univ. Pr., 1980).

10. Judith Axler Turner, "Campus Libraries Seen Threatened by Other Sources of Information," Chronicle of Higher Education 31:30 (Dec. 4, 1985).

11. Ibid., p.30.

12. Elizabeth Frick, "Information Structure and Bibliographic Instruction," Journal of Academic Librarianship 1:12-14 (Sept. 1975); Thelma Friedes, Literature and Bibliography of the Social Sciences (Los Angeles: Melville, 1973); Sharon Rogers, "Research Strategies: Bibliographic Instruction for Undergraduates," Library Trends 29:69-81 (Summer 1980); Cerise Oberman and Rebecca Linton, "Guided Design: Teaching Library Research on Problem Solving," p.111-34 in Cerise Oberman and Katina Strauch, eds., Theories of Bibliographic Education (New York: Bowker, 1982).

13. Dorice L. Horne, "Teaching Microcomputer Applications in the Library," Bulletin of the American Society for Information Science 12:23-25 (Oct.-Nov. 1985); Wayne Wilson, "Computer-Assisted Instruction in an Academic Library," Information Technology and Libraries 2:389-93 (Dec. 1983).

14. Betsy Baker, "A Conceptual Framework for Teaching Online Catalog Use," Journal of Academic Librarianship 12:90-96 (May 1986); Brian Nielsen, "What They Say and What They Do: Assessing Online Catalog Use Instruction through Transaction Monitoring," Information Technology and Libraries 5:28-35 (Mar. 1986).

15. Evan Ira Farber, "Catalog Dependency," Library Journal 109:325-28 (Feb. 15, 1984); David R. McDonald and Susan E. Searing, "Bibliographic Instruction and the Development of Online Catalogs," College \& Research Libraries 44:5-11 (Jan. 1983).

16. Fern Brody and Marilyn Whitmore, "Microcomputer Searching Laboratory: An Experiment in End-User Searching," Poster session at American Library Association Annual Conference, New York, June 28, 1986.

17. Susan Swords Steffen, "College Faculty Goes Online: Training Faculty End Users," Journal of Academic Librarianship 12:147-51 (July 1986); Linda Friend, "Independence at the Terminal: Training Student End Users to Do Online Literature Searching," Journal of Academic Librarianship 11:136-41 (July 1985). For a discussion of the librarian's role as search consultant, see Abigail Hubbard and Barbara Wilson, "An Integrated Information Management Program . . . Defining a New Role for Librarians in Helping End-Users," Online 10:15-23 (Mar. 1986).

18. Connie Miller and Patricia Tegler, "Online Searching and the Research Process," College \& Research Libraries 47:370-73 (July 1986).

19. Fred F. Hofstetter, The Ninth Summative Report of the Office of Computer-Based Instruction (Newark: Univ. of Delaware, 1984)., p.122-24; Mitsuko Williams and Elizabeth B. Davis, "Evaluation of PLATO Library Instructional Lessons," Journal of Academic Librarianship 5:14-19 (Mar. 1979).

20. Susan M. Rawlins, "Technology and the Personal Touch: Computer-Assisted Instruction for Library Student Workers, ' Journal of Academic Librarianship 8:26-29 (Mar. 1982); Louise Garraux Glogoff, Barbara C. Dean, and Anne L. Highsmith, "Computer-Based Training Program for Cataloging Department Staff," Journal of Academic Librarianship 10:23-28 (Mar. 1984).

21. Patricia D. Arnott and Deborah E. Richards, "Using the IBM Personal Computer for Library Instruction," Reference Services Review 13:69-72 (Spring 1985).

22. Susan S. Lytle, "Instructional Use of Microcomputers in a University Research Library," Poster session at American Library Association Annual Conference, Los Angeles, June 25, 1983.

23. Horne, "Teaching Microcomputer Applications"; see also Linda J. Piele, Judith Pryor, and Harold W. Tuckett, "Teaching Microcomputer Literacy: New Roles for Academic Librarians," College \& Research Libraries 47:374-78 (July 1986). 
24. Harold B. Shill, "Computer-Based Education and the Academic Library," West Virginia Libraries 37:23-28 (Winter 1984).

25. Horne, "Teaching Microcomputer Applications"; Piele and others, "Teaching Microcomputer Literacy"; Shill, "Computer-Based Education."

26. Pamela Snelson, "Microcomputers in Academe: Challenges and Opportunities for Libraries," West Virginia Libraries 38:6-13 (Winter 1985); Lee David Jaffe, "The Role of the Academic Library in Campus Microcomputer Services," Small Computers in Libraries 6:27-29 (June 1986).

27. Roger Phillips, "A Public Access Videotex Library Service," Online 6:34-39 (Sept. 1982), describes contracting for and use of The Source, CompuServe, and Dow-Jones News Retrieval Service in the Wheaton College Library.

28. Kathryn W. Hickerson, "Computer Network to Aid Engineers in Specifying Materials," Engineering Times, Feb. 1986, p.7.

29. See Ching-chih Chen and Peter Hernon, eds., Numeric Databases (Norwood, N. J.: Ablex, 1984) for an excellent overview of the statistical/numeric databases available and their importance to libraries.

30. Trudi Bellardo and Judy Stephenson, "The Use of Online Numeric Databases in Academic Libraries: A Report of a Survey," Journey of Academic Librarianship 12:152-57 (July 1986).

31. Ibid., p.154.

32. Edwin Brownrigg, Clifford Lynch, and Mary Engle, "Technical Services in the Age of Electronic Publishing," Library Resources \& Technical Services 28:59-67 (Jan./Mar. 1984). Planning considerations for integrating print and electronic materials in library collections are addressed in Karen A. Schmidt, "Electronic Publishing and the Academic Library," Paper presented at the Library and Information Technology Association Conference, Baltimore, Sept. 19, 1983.

33. F. Wilfrid Lancaster, Libraries and Librarians in an Age of Electronics (Arlington, Va.: Information Resources Pr. 1982); F. W. Lancaster, "The Paperless Society Revisited," American Libraries 16:553-55 (Sept. 1985).

34. John C. Gale, "The Information Workstation: A Confluence of Technologies Including the CDROM," Information Technology and Libraries 4:137-39 (June 1985).

35. Pamela Q. J. Andre, "Evaluating Laser Videodisc Technology for the Dissemination of Agricultural Information," Information Technology and Libraries 4:139-47 (June 1985).

36. Victor Rosenberg, "The Scholar's Workstation," College \& Research Libraries News 46:546-49 (Nov. 1985).

37. Donald E. Riggs, Strategic Planning for Library Managers (Phoenix: Oryx, 1984); Elizabeth J. Wood, "Strategic Planning and the Marketing Process," Journal of Academic Librarianship 9:15-20 (Mar. 1983).

38. Robert J. Bassett and others, Report of the Study Group on Electronic Access to Information (Bethesda, Md.: ERIC Document Reproduction Service, ED 254 250, 1984); Colleen Cook and others, Future Information Services at the Texas A\&M University Library: Background and Recommendations (Bethesda, Md.: ERIC Document Reproduction Service, ED 252 242, 1984).

39. James L. Morrison, William L. Renfro, and Wayne I. Boucher, Futures Research and the Strategic Planning Process: Implications for Higher Education, ASHE-ERIC Higher Education Research Report, no.9 (Washington, D.C.: Association for the Study of Higher Education, 1984), p.22-23.

40. George Keller, Academic Strategy: The Management Revolution in Higher Education (Baltimore: Johns Hopkins Univ. Pr. 1983), p.12.

41. Ibid., p.12.

42. John M. Budd and David G. Robinson, "Enrollment and the Future of Academic Libraries," Library Journal 111:43-46 (Sept. 15, 1986).

43. Keller, p.13.

44. Carol Frances, "1986: Major Trends Shaping the Outlook for Higher Education," AAHE Bulletin 38:3 (Dec. 1985).

45. Deborah Burnett Strother, "Latchkey Children: The Fastest-Growing Special Interest Group in the Schools," Phi Delta Kappan 66:290-93 (Dec. 1984).

46. Constance Holden, "Will Home Computers Transform Schools?"' Science 225:296 (July 20, 1984).

47. Ibid., p. 296.

48. U. S. National Commission on Excellence in Education, A Nation at Risk: The Imperative for Education Reform: A Report to the Nation and to the Secretary of Education, U. S. Department of Education (Washington, D.C.: Commission on Excellence in Education, 1983), p.26.

49. Statistical Abstract of the United States, 1987, 107th ed. (Washington, D.C.: U.S. Dept. of Commerce, 1987), p.132. 
50. Carol Tenopir, "Online Searching in Schools," Library Journal 111:60 (Feb. 1, 1986).

51. Anne S. Caputo, "DIALOG in the School: Use of DIALOG's Classroom Instruction Program in Secondary Schools," Education Libraries 11:6 (Winter 1986); Bev Smith, "Student Searchers: Are They Out There?"' Information Today 1:1-3 (Mar. 1984).

52. Telephone conversation with Anne Caputo, Dialog Information Services, Apr. 17, 1987.

53. Tenopir, p.60-61.

54. John Naisbitt, Megatrends: Ten New Directions Transforming Our Lives (New York: Warner, 1982), p.11-38.

55. Legislative Report of the ALA Washington Office, January-June 1986 (Washington, D.C: American Library Assn., 1986), p.22.

56. For a good discussion of the Chapter 2 program, see Anne F. Henderson, "Chapter 2: For Better of Worse?" Phi Delta Kappan 67:597-601 (April 1986).

57. Lancaster, Libraries and Librarians in an Age of Electronics, p.61.

58. Lancaster, "The Paperless Society Revisited," p.554.

59. Ibid., p.555.

60. Kenneth Dowlin, The Electronic Library: The Promise and the Process (New York: Neal-Schuman, 1984).

61. Carlton Rochell, "Telematics-2001 A.D.," Library Journal 107:1809-15 (Oct. 1, 1982).

62. Keller, p.14.

63. Ibid., p.13-14.

64. Elinor G. Barber and Robert P. Morgan, "The Impact of Foreign Graduate Students on Engineering Education in the United States," Science 236:33-37 (Apr.3, 1987).

65. Charles Osburn, Academic Research and Library Resources: Changing Patterns in America (Westport, Conn.: Greenwood, 1979), p.3-38.

66. Robert M. Rosenzweig with Barbara Turlington, The Research Universities and Their Patrons (Berkeley: Univ. of California Pr., 1982); Ellen McDonald, "University-Industry Partnerships: Premonitions for Academic Libraries," Journal of Academic Librarianship 11:82-87 (May 1985); Herbert S. White, "Public Libraries and the Political Process," Library Journal 111:49-51 (June 15, 1986); W. Randall Wilson, "Partners in Economic Development," Library Journal 111:32-34 (Mar. 15, 1986).

67. See John W. McCredie, ed., Campus Computing Strategies (Bedford, Mass.: Digital Pr. 1983). See also "The 'Star Wars' Universities: Carnegie-Mellon, Brown, and M.I.T.," in Marc L. Tucker, ed., "Computers on Campus: Working Papers," Current Issues in Higher Education no.2:3-24 (1983-84).

68. See Nina Matheson and John A. D. Cooper, "Academic Information in the Academic Health Sciences Center: Roles for the Library in Information Management, Part 2," Journal of Medical Education 57:1-93 (Oct. 1982); Patricia M. Battin, "The Library: Center of the Re-Structured University," in "Colleges Enter the Information Society," Current Issues in Higher Education no.1:25-31 (1983-84).

69. Linda Friend, "Access to External Databases: New Opportunities to Interface," Wilson Library Bulletin 60:24-26 (Nov. 1985).

70. Derek J. de Solla Price, Little Science, Big Science New York: Columbia Univ. Pr. 1963); see also Diana Crane, Invisible Colleges: Diffusion of Knowledge in Scientific Communities (Chicago: Univ. of Chicago Pr., 1972); and William D. Garvey, Communication, The Essence of Science: Facilitating Information Exchange among Librarians, Scientists, Engineers, and Students (New York: Pergamon Pr., 1979).

71. Lancaster, p.198; John Shelton Lawrence, The Electronic Scholar: A Guide to Academic Microcomputing (Norwood, N. J.: Ablex, 1984).

72. Starr Roxanne Hiltz and Murray Turoff, The Network Nation: Human Communication via Computer (Reading, Mass.: Addison-Wesley, 1978); Priscilla Oakeshott, "The 'BLEND' Experiment in Electronic Publishing," Scholarly Publishing 17:25-36 (Oct. 1985).

73. Several years ago Naisbitt (Megatrends, p.24) estimated that $6,000-7,000$ scientific articles are written daily. Fortunately, not all of them are published. For a discussion of user behaviors for avoiding information overload and of potential assistance librarians can provide, see Joel Rudd and Mary Jo Rudd, "Coping with Information Overload: User Strategies and Implications for Librarians," College \& Research Libraries 47:315-22 (July 1986).

74. Battin, "The Library"; Pat Molholt, "On Converging Paths: The Computer Center and the Library," Journal of Academic Librarianship 11:284-88 (Nov. 1985); Raymond K. Neff, "Merging Libraries and Computer Centers: Manifest Destiny or Manifestly Deranged? An Academic Services 
Perspective," EDUCOM Bulletin, 20:12-16 (Winter 1985).

75. Smith, p.15-23.

76. Lancaster, Libraries and Librarians in an Age of Electronics, p.109-24.

77. Stephen K. Stoan, "Computer Searching: A Primer for the Uninformed Scholar," Academe 68:10-15 (Nov.-Dec. 1982).

78. Joseph Raben, "Advent of the Post-Gutenberg University," Academe 69:25-26 (Mar.-Apr. 1983).

79. Naisbitt, p.85-86.

80. Thomas J. Peters and Robert A. Waterman, In Search of Excellence: Lessons from America's Best-Run Companies (New York: Warner, 1982).

81. Malcolm G. Scully, "Study Finds Colleges Torn by Divisions, Confused over Roles," Chronicle of Higher Education 38, no.1:1,16-21 (Nov. 5, 1986).

82. Ibid., p.21.

83. Patricia Senn Breivik, "Putting Libraries Back in the Information Society," American Libraries 16:723 (Nov.1985).

84. Lancaster, Libraries and Librarians in an Age of Electronics, p.151-67.

85. Bob Dylan, "The Times, They Are A-Changin'," (New York: M. Witmark, 1963). 


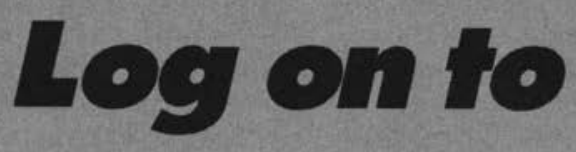

\section{Computer \&}
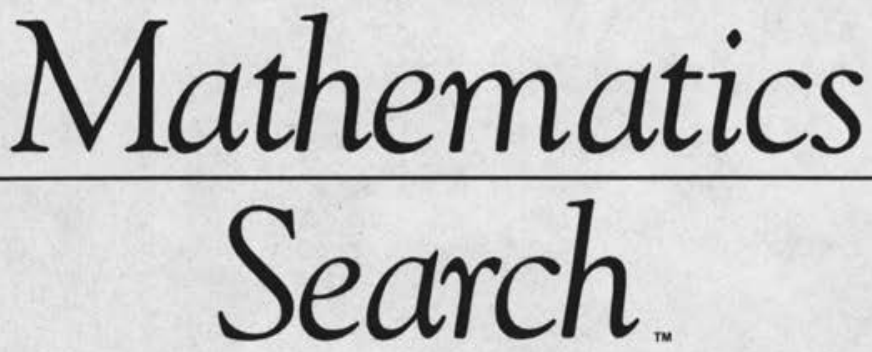

\begin{tabular}{|c|c|}
\hline $\begin{array}{l}\text { ematics Search, you can } \\
\text { search nearly } 400 \text { key jour- } \\
\text { nals in mathematics, com- } \\
\text { puter science, statistics, operations research, } \\
\text { and related fields. And you can locate } \\
\text { hardware, software, and database reviews, } \\
\text { along with articles on computer science } \\
\text { and mathematics applications appearing in } \\
\text { more than } 6,000 \text { additional journals in sci- } \\
\text { ence, medicine, business, the social sci- } \\
\text { ences, and the arts \& humanities. }\end{array}$ & $\begin{array}{l}\text { tion, title words, or } \\
\text { cited references. Or } \\
\text { search by Research } \\
\text { Fronts to find the core } \\
\text { literature of many research }\end{array}$ \\
\hline $\begin{array}{l}\text { Computer \& Mathematics Search makes } \\
\text { searching this literature fast and easy by } \\
\text { offering a variety of access points to each } \\
\text { item. Search by author name, author affilia- }\end{array}$ & $\begin{array}{l}\text { Log on to Computer \& Mathematics } \\
\text { Search. And find all the computer } \\
\text { and mathematics information you're } \\
\text { searching for. Available on BRS. }\end{array}$ \\
\hline Tel: 1215 & $\begin{array}{r}91987 \\
101-4869\end{array}$ \\
\hline
\end{tabular}




\section{ACQUISITION PERSPECTIVES}

6. Book House is in its fourth generation of automation. Our custom software allows us the flexibility to accept orders generated through your computerized system or in the mail. Our policy is to develop a working compatibility with the automated system in your library to facilitate receiving orders, transmitting open order reports and invoices electronically.

Let's explore interfacing your automation with ours.

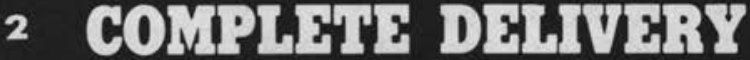

\section{OPHN OADAR RAPORTS}

\section{4 DHWW} ECCURFII B00R

CALL TOLL-FREE TODAY

1-800-248-1146

In Canada \& Michigan CALL COLLECT (517) 849-2117

OCLC Vendor No. 17397

SAN $169-3859$

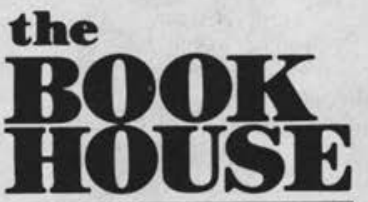

JOBBERS SERVING LIBRARIES WITH ANY BOOK IN PRINT SINCE 1962 208 WEST CHICAGO STREET JONESVILLE, MICHIGAN 49250 


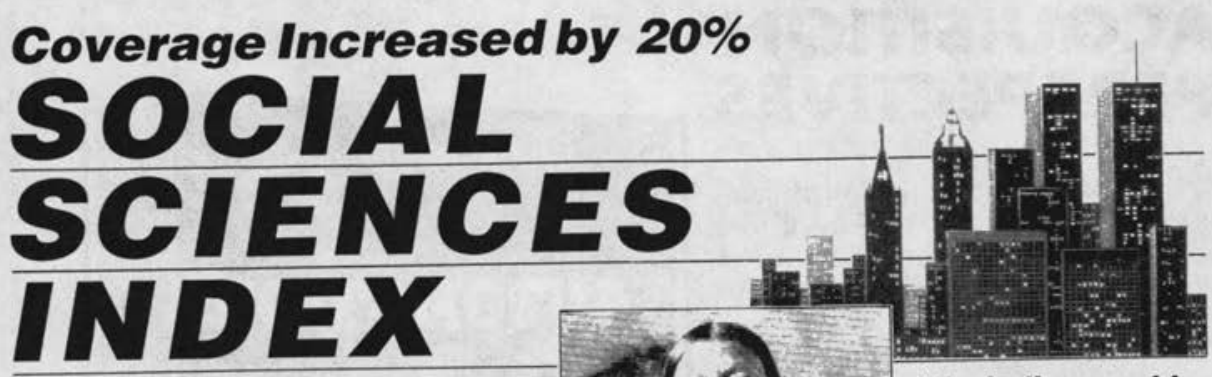

Following a content study by the ALA's Committee on Wilson Indexes, this singlealphabet subjectauthor index expands its coverage to include 68 additional periodicals, for a total of 353 publications, beginning with the June 1987 issue.

\section{An Up-to-Date Guide to the Social \\ Sciences}

An authoritative, easy-to-use guide to information contained in leading English-language periodicals in all areas of the social sciences, Social Sciences Index offers coverage of these and other areas:

\section{-Anthropology •Area Studies} - Community Health \& Medical Care $\cdot$ Consumer Affairs -Demography •Economics - Ethnic Studies - Future Studies • Geography •Human Ecology International Relations - Law \& Criminology -Marital \& Family Therapy -Minority Studies •Political Science •Planning \& Public Administration $\bullet$ Police Science \& Corrections -Psychiatry •Psychology - Social Work \& Public Welfare -Sociology • Urban Studies

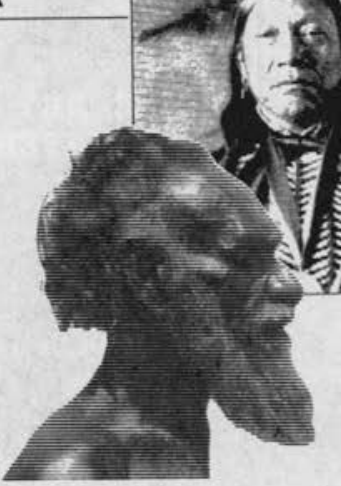

\section{Organized} for Easy Access Easy-to-Use, Social Sciences Index offers:

- Easy Access by Author or Subject

Controlled subject headings and plain-language terminology make it easy to find what you need.

- Specific Subheadings Help you refine your search for information.

- Extensive Cross References Help you expand your information search with See and See Also references.

- Name Authority Control Ensures that the names of persons, organizations, and institutions will be uniform whenever they appear.

n Book Reviews Provides an alphabetical list of reviews of current books in the social sciences.
"An indispensable tool for access to the periodical literature of the social sciences." -AMERICAN REFERENCE BOOKS ANNUAL

\section{To Order}

A subscription to Social

Sciences Index brings you quarterly paperbound issues, plus a permanent clothbound annual cumulation. This index is sold on the service basis. For a checklist to determine your noobligation price quotation, call the toll-free number below.

\section{Now-Online and CD-ROM Access to} Social Sciences Index Social Sciences Index is also available online through the WILSONLINE ${ }^{\circ}$ information retrieval system, WILSEARCH software for direct patron access, and the WILSONDISC CD-ROM information retrieval system.

For information call the toll-free number below.

\section{To Order Call Toll-Free 1-800-367-6770}

In New York State call 1-800-462-6060; in Canada call collect 212-588-8400.

\section{A THE H.W. WILSON COMPANY}

950 University Avenue

Bronx, New York 10452

(212) $588-8400$ 